\title{
FOTO DOKUMENTER BENGKEL ANDONG MBAH MUSIRAN: PENERAPAN DAN TINJAUAN METODE EDFAT DALAM PENCIPTAAN KARYA FOTOGRAFI
}

\author{
Pamungkas Wahyu Setiyanto \\ Irwandi \\ Dosen Jurusan Fotografi, Fakultas Seni Media Rekam, ISI Yogyakarta \\ Jl. Parangtritis Km 6,5 Bantul, Yogyakarta \\ No. Hp.: +628122969624,E-mail: pamungkaswahyusetiyanto@gmail.com \\ No.Hp.: 081328656252,E-mail: insinyurwandi@yahoo.com
}

\begin{abstract}
Abstrak
Metode Entire, Detail, Frame, Angle, Time (EDFAT) belum begitu dikenal dalam dunia fotografi. Akan tetapi, metode terebut sebenarnya sudah lazim di kalangan praktisi, khususnya fotografer jurnalistik. Untuk itu, penelitian dan penerapan EDFAT menjadi penting dilakukan, mengingat dalam kenyataannya metode tersebut sangat efektif dan efisien. Peneletian ini merupakan upaya untuk memahami dan menerapkan metode EDFAT. Subjek penelitian ialah Bengkel Andong MBah Musiran yang berada di kawasan Jotawang, Yogyakarta. Hasil penelitian menunjukkan bahwa metode EDFAT memang dapat diterapkan dalam penciptaan karya fotografi, terlebih jika sebelum pemotretan, fotografer terlebih dahulu menghimpun informasi yang berkaitan dengan subjek pemotretan.
\end{abstract}

Kata kunci: fotografi dokumenter, Bengkel Andong Mbah Musiran, metode EDFAT

\begin{abstract}
Documentary Photography of the Workshop of Andong Mbah Musiran: Implementation and Review of the EDFAT Method in the Photography Creation. Entire, Detail, Frame, Angle, Time (EDFAT) method has not been well-recognized in the academic world of photography. However, this method has been pretty familiar among the practitioners, especially those in the journalism photography. Therefore, the research and the implementation of EDFAT are very important to do, especially that in reality this method is every effective and efficient. This research is an effort to comprehend and apply the method of EDFAT. Subject of this research is the workshop of andong (horse cart) owned by Mbah Musiran located in Jotawang, Yogyakarta. The result of this research shows that the method of EDFAT could be implemented in the creation of photography, particularly before the photo shoot, the photographer collects all related information earlier.
\end{abstract}

Keywords: documentary photography, workshop of Andong Mbah Musiran, method of EDFAT

\section{PENDAHULUAN}

Penciptaan karya foto dokumenter dalam dunia fotografi sudah mulai berkembang seiring dengan kemajuan dunia fotografi. Sifat fotografi dokumenter yang selalu fleksibel dan mengikuti perkembangan peradaban manusia menjadikannya tidak akan dilibas oleh zaman, bahkan akan selalu dinanti kehadirannya. Mengikuti perkembangan fotografi dokumenter dewasa ini merupakan hal yang cukup menarik karena, pertama, bahwa fotografi dokumenter dapat memperluas wawasan penikmatnya, mengingat foto dokumenter dibuat untuk kepentingan yang beragam, dari yang bersifat pribadi sampai pada kepentingan yang lebih luas, yaitu kepentingan jurnalistik. Kedua, dari karya foto dokumenter audien dapat menikmati foto dokumenter sebagai sebuah karya seni 
yang merupakan ekspresi ungkapan estetik si fotografer.

Karya-karya fotografi dokumenter untuk kepentingan jurnalistik dan sebagai karya seni dalam penciptaannya membutuhkan metode dan keterampilan tertentu. Fotografer seharusnya tidak sekadar memotret segala hal dan hanya menyeleksi foto-foto yang dianggap layak, tetapi lebih jauh dari itu, yaitu memikirkan pola alur, bobot, dan nilai penting yang akan disampaikan kepada audien.

Foto dokumenter yang diciptakan oleh para jurnalis foto/pewarta foto biasanya lebih terstruktur. Hal ini karena pada umumnya para pewarta foto dalam mencipta karya fotografi dokumenter menerapkan metode EDFAT. Metode ini diperkenalkan oleh Walter Cronkite School of Journalism and Telecommunication Arizona State University yang merupakan akronim dari Entire, Detail, Frame, Angle, dan Time. Tujuan penerapan EDFAT ialah menggambarkan aspek-aspek yang perlu diperhatikan dalam pemotretan guna mendapatkan foto-foto yang komprehensif, variatif, baik dari sisi fotografis maupun dari segi pemaparan kejadian atau peristiwa.

Akan tetapi, metode EDFAT yang sudah diterapkan dalam praktik pemotretan oleh para pewarta foto di dunia fotografi jurnalistik, ternyata belum begitu dikenal di ranah akademis fotografi. Tampaknya, "Pengaruh" istilah decisive moment milik Henri Cartier Bresson (HCB) terlalu dominan sehingga foto jurnalistik dan dokumenter selalu diidentikkan dengan istilah tersebut. Memang, istilah HCB tersebut sangat penting dalam foto jurnalistik dan dokumenter, namun upaya untuk memperolehnya juga harus dikuasai. Salah satu upaya untuk mendapatkan decisive moment ialah penerapan metode EDFAT dalam pemotretan.
Penelitian ini, selain bertujuan untuk menerapkan metode EDFAT, juga bertujuan untuk mengenali dan memahaminya. Diharapkan setelah penelitian, metode EDFAT akan dipaparkan secara tuntas dan dijadikan salah satu materi pembelajaran fotografi jurnalistik di Jurusan Fotografi, FSMR, ISI Yogyakarta sehingga juga dapat tersosialisasikan dengan baik.

Objek penciptaan karya fotografi dokumenter yang akan dijadikan sampel penerapan metode EDFAT dalam penelitian ini adalah Bengkel Andong Mbah Musiran yang ada di Desa Salakan, Jotawang, Yogyakarta. Dipilihnya bengkel andong sebagai sampel penelitian didasari beberapa hal, antara lain pertimbangan ketersediaan data, kelengkapan bengkel andong sebagai suatu objek yang dapat menjadi "cerita", dan pertimbangan pelestarian kebudayaan dan tradisi Yogyakarta melalui visualisasi fotografis. Pemilihan bengkel andong juga diharapkan menjadikan penelitian ini bernilai multiguna, yakni sebagai penguatan praktik fotografi jurnalistik yang berorientasi pada nilai intrinsik dan nilai "jual"-nya; peningkatan keterampilan mahasiswa Jurusan Fotografi, ISI Yogyakarta sebagai lembaga pendidikan fotografi di Indonesia; pendokumentasian salah satu bagian kebudayaan tradisional Indonesia, khususnya Yogyakarta; dan dapat memperkaya wacana ranah fotografi seni di Indonesia.

Permasalahan yang akan dipaparkan di sini sebenarnya mencakup dua hal, yaitu masalah penelitian dan penciptaan. Hal ini perlu dilakukan supaya hasil penelitian dapat menjelaskan bagaimana memahami dan menggunakan "kaca mata" EDFAT, khususnya ketika pemotret berhadapan dengan situasi tertentu yang akan didokumentasikan. Dalam kata lain, EDFAT digunakan untuk melihat 
sesuatu berdasarkan konteks tertentu. Di sisi lain, setelah pemotret memahami konteks dan objek pemotretannya, penerapan EDFAT akan dilakukan dalam tataran operasional/pemotretan. Untuk itu, masalah dalam penelitian ini ialah bagaimana menerapkan EDFAT untuk memahami konteks bengkel Andong Mbah Musiran sebagai objek pemotretan dan bagaimana menerapkan EDFAT pada tataran aspek pemotretannya. Upaya tersebut juga dilakukan untuk mengevaluasi metode EDFAT, baik dari sisi keunggulan maupun kelemahannya ketika diterapkan di lapangan. Melalui penelitian dan penciptaan ini pula, akan lebih memantapkan wawasan jawaban apakah metode EDFAT dapat dan layak dikembangkan dalam materi pembelajaran fotografi jurnalistik.

\section{PENCIPTAAN DAN PENELITIAN TERDAHULU}

Tentunya sudah banyak fotografer yang membuat foto tentang Andong. Fotografer yang membuat karya tentang andong, antara lain Nugroho (2006) dengan judul tugas akhir S-1 Jurusan Fotografi, FSMR, ISI Yogyakarta "Kehidupan Andong di Yogyakarta dalam Fotografi Dokumentasi". Nugroho memaparkan pemotretan andong dalam konteks sebagai alat transportasi tradisional secara umum. Dari sisi aspek produksi, cakupan pembahasan yang dilakukan terlalu luas. Pemotretan yang dilakukan Nugroho merupakan proses dari persiapan dan suasana ketika andong melakukan pekerjaan, belum menyentuh aspek penerapan EDFAT. Meskipun demikian, pemaparan Nugroho dapat dijadikan pijakan awal untuk membahas aspek penerapan metode EDFAT dalam penciptaan foto dokumenter bengkel andong.

Dalam konteks yang berbeda, metode EDFAT juga pernah digunakan untuk menganalisis foto-foto jurnalisitk oleh Mugdhiyana (2011) dalam penelitiannya yang berjudul "Analisis Isi Foto
Jurnalistik Mengenai Kerusuhan Mesir pada Harian Kompas". EDFAT dalam penelitian ini hanya digunakan dalam membahas foto-foto tentang berbagai kerusuhan seputar demonstrasi untuk menjatuhkan Hosni Mubarak, bukan digunakan sebagai metode penciptaan. Penelitian yang cukup dekat dengan penelitian kali ini ialah apa yang dilakukan oleh Shobri (2010) dalam laporan yang bejudul "Fotografi Pementasan Teater dengan Teknik Freeze Motion di Dalam Gedung Pertunjukan (Analisis Visual Foto Pementasan Maaf-MaafMaaf dan Sayang Ada Orang Lain Produksi Teater Lakon UPI Bandung)". EDFAT dalam penelitian Shobri digunakan untuk menganalisis dan memotret, namun tidak ditinjau ulang secara kritis. Di samping itu, objek penelitiannya pun berbeda, yaitu pementasan teater. Dari sisi tujuan, penelitian Sobri sangat berbeda dengan penelitian kali ini, yaitu menjelaskan, menerapkan, dan meninjau ulang metode EDFAT dari sisi kelebihan dan kekurangannya. Berdasarkan tinjauan pustaka yang telah dilakukan, penelitian dan penciptaan foto dokumenter bertema bengkel andong di Yogyakarta dengan metode EDFAT belum pernah dilakukan.

\section{LANDASAN TEORI}

\section{Fotografi Dokumenter}

Pendekatan foto dokumenter akan digunakan dalam penelitian dan penciptaan ini. Genre foto dokumenter dianggap tepat untuk merefleksikan objek karena foto dokumenter menyajikan foto-foto secara, gamblang tanpa adanya rekayasa, bisa langsung bercerita tentang objek yang dimaksud sehingga diharapkan penikmat foto bisa ikut merasakan sebuah fenomena seperti apa adanya. Ini agak berbeda dengan genre esai foto, yang menempatkan opini fotografer dalam posisi yang penting.

Demikianlah, fotografer dokumenter harus menyampaikan kebenaran tanpa adanya 
tendensi maupun ideologi pribadi. Buku TimeLife Books memberi pengertian tentang foto dokumenter sebagai "A depiction of the real world by photographer whose intent is to communicate something of importance-to make a comment-that will be understood by viewer." (Tim Editor, 1972). Selain itu, dalam buku yang lain disebutkan bahwa "....documentary photography has also created important records thatprovidetangible evidencesupported by great visual detail, cast the compelling impression of truth, allow viewers to occupy the position of the photographer, serve as an impartial and faithful witness to life's events, and freeze an instant of time so that places and events may be later studied and restudied. (Peres, 2007). Dari pengertian tersebut pencipta memilih fotografi dokumenter dalam penelaahan, penerapan, dan evaluasi metode EDFAT untuk pembuatan fotografi dokumenter bengkel andong.

\section{Metode $E D F A T$}

Metode EDFAT di dalam lingkungan akademisi belum sering digunakan, namun sudah sangat dikenal dan diterapkan di lingkungan profesional khususnya bagi para wartawan atau pewarta foto baik skala nasional maupun internasional. Tidak banyak sumber pustaka yang menjelaskan metode EDFAT. Kebayakan pernyataan tentang EDFAT dituliskan tanpa menyertakan sumbernya. Satu-satunya penulis buku yang mengutarakan EDFAT adalah Streisel (2007). Ia menyatakan bahwa EDFAT perlu dipertimbangkan ketika seorang fotografer melakukan pemotretan. Secara cukup lengkap, Shobri (2010) dan wartawan senior Harian Kompas, Edy Hasby (www. eddyhasby.com) menguraikan kelima aspek EDFAT sebagai berikut.

\section{a. E=Entire}

Dikenal juga sebagai 'established shot', suatu keseluruhan pemotretan yang dilakukan begitu melihat suatu peristiwa atau bentuk penugasan lain. Untuk mengincar atau mengintai bagian-bagian untuk dipilih sebagai objek.

\section{b. $D=$ Detail}

Suatu pilihan atas bagian tertentu dari keseluruhan pandangan terdahulu (entire). Tahap ini adalah suatu pilihan pengambilan keputusan atas sesuatu yang dinilai paling tepat sebagai 'point of interest'.

\section{c. $F=$ Frame}

Suatu tahapan saat mulai membingkai suatu detil yang telah dipilih. Fase ini mengantar seorang calon foto jurnalis mengenal arti suatu komposisi, pola, tekstur dan bentuk subjek pemotretan dengan akurat. Rasa artistik semakin penting dalam tahap ini.

\section{d. A=Angle}

Tahap ketika sudut pandang menjadi dominan, ketinggian, kerendahan, level mata, kiri, kanan dan cara melihat. Fase ini penting mengonsepsikan aspek visual apa yang diinginkan.

\section{e. $T=$ Time}

Tahap penentuan waktu penyinaran dengan kombinasi yang tepat antara diafragma dan kecepatan atas keempat tingkat yang telah disebutkan sebelumnya. Pengetahuan teknis atas keinginan membekukan gerakan atau memilih ketajaman ruang adalah satu prasyarat dasar yang sangat diperlukan.

Selain dari sumber tersebut, metode EDFAT sering diutarakan lewat laman-laman fotografi, baik di dalam maupun di luar negeri misalnya, University of California yang memuat EDFAT sebagai salah satu materi dalam silabus mata kuliah fotografi jurnalistik (http://www.uco.edu, diakses tanggal 17 Januari 2012, pukul 17:16 WIB); dan 
Jim Bryant yang menyatakan bahwa EDFAT adalah salah satu metode art of seeing (http://www.digitalphotography-school.com/EDFAT-the-art-of-seeing diakses tanggal 17 Januari 2012, pukul 17:18 WIB)

\section{PEMBAHASAN}

\section{Gambaran Singkat Bengkel Andong Mbah Musiran}

Bengkel andong Mbah Musiran saat ini bertempat di kawasan Jotawang, Salakan, Yogyakarta. Secara fisik bengkel ini memiliki luas $400 \mathrm{~m}^{2}$ yang terdiri dari dua area, yaitu area terbuka dan area beratap. Area terbuka merupakan tempat untuk memarkir andong yang menunggu giliran perbaikan berikut kudanya, sedangkan area beratap merupakan bagian utama bengkel tersebut. Di area beratap inilah andong-andong diperbaiki. Area beratap di Bengkel Andong Mbah Musiran terbagi menjadi dua ruangan, yaitu ruangan depan yang digunakan sebagai lokasi perbaikan dan perakitan andong, serta ruangan belakang yang digunakan untuk pekerjaan yang membutuhkan pemanasan besi. Kedua ruangan ini merupakan bagunan semipermanen.

Jumlah pekerja di bengkel ini hanya dua orang, Wido (45 tahun) dan Jono (40 tahun). Keduanya putra Mbah Musiran. Mbah Musiran saat ini sudah mengurangi aktivitasnya di bengkel mengingat usianya yang sudah lanjut. Saat ini tanggung jawab pengelolaan bengkel diserahkan kepada Jono.

Cakupan utama pekerjaan yang dapat dilakukan dilakukan di bengkel ini ialah perbaikan andong-andong domestik yang lazim dijadikan sarana transportasi umum di Yogyakarta. Perbaikan as roda, penggantian ban, perbaikan suspensi andong, dan perbaikan kecil lainnya merupakan pekerjaan rutin di bengkel ini. Selain itu, bengkel ini juga sering menerima pesanan pembuatan kereta kuda yang datang dari manca negara seperti Inggris dan Belanda.

Peralatan yang digunakan di bengkel ini bisa dikatakan cukup sederhana, namun pada dasarnya digunakan untuk menangani pekerjaan dengan material bahan baku kayu dan besi. Alatalat itu antara lain: obeng, tang, kunci pas, senar, gergaji kayu, gergaji besi, dan tanggem. Bengkel ini beroperasi setiap hari kerja pukul 09.00-17.00 WIB.

\section{Analisis dan Penerapan EDFAT pada Bengkel Andong Mbah Musiran}

Berdasarkan gambaran situasi yang diperoleh di lokasi bengkel, hasil pemotretan dengan penerapan EDFAT dapat dilihat dalam fotofoto berikut ini.

\section{Entire: Pemotretan objek foto dengan long shot dan angle tertentu}

Bagian-bagian utama bengkel andong disajikan secara long shot dan medium shot.

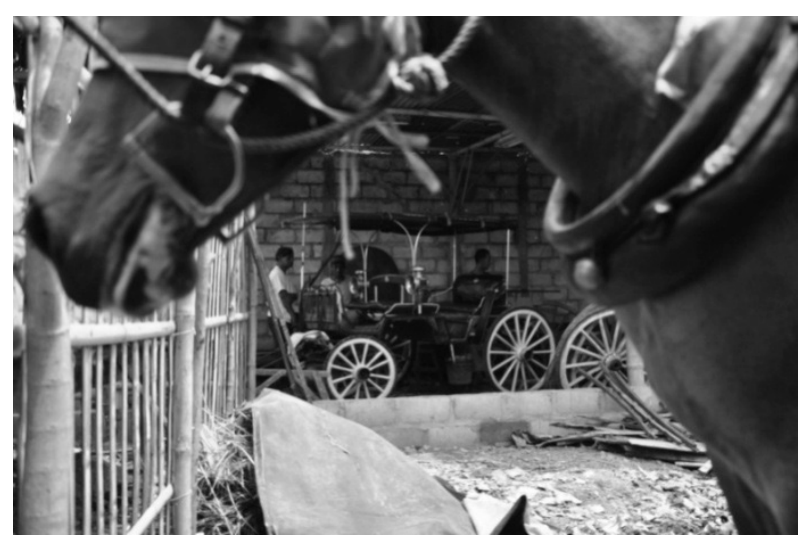

Entire 1. Kuda yang sedang diistirahatkan dan andong yang sedang diperbaiki.

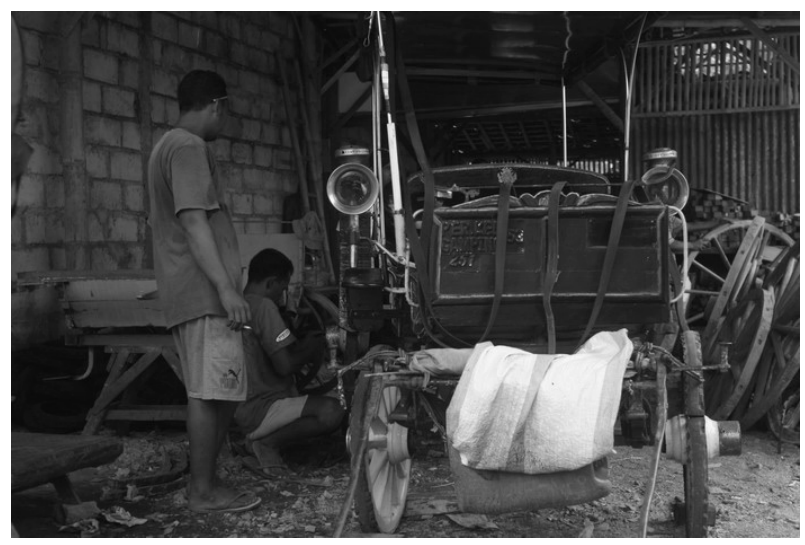

Entire 2. Foto suasana bagian depan bengkel andong. 


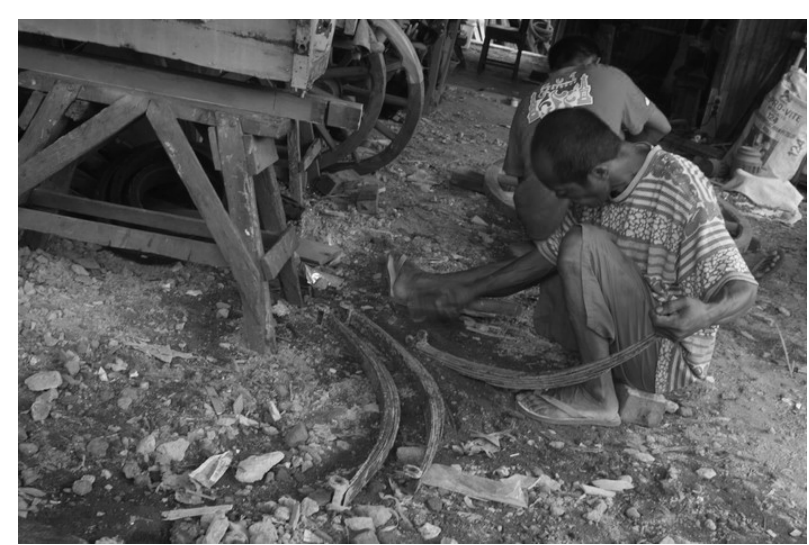

Entire 3. Foto aktivitas perbaikan suspensi andong.

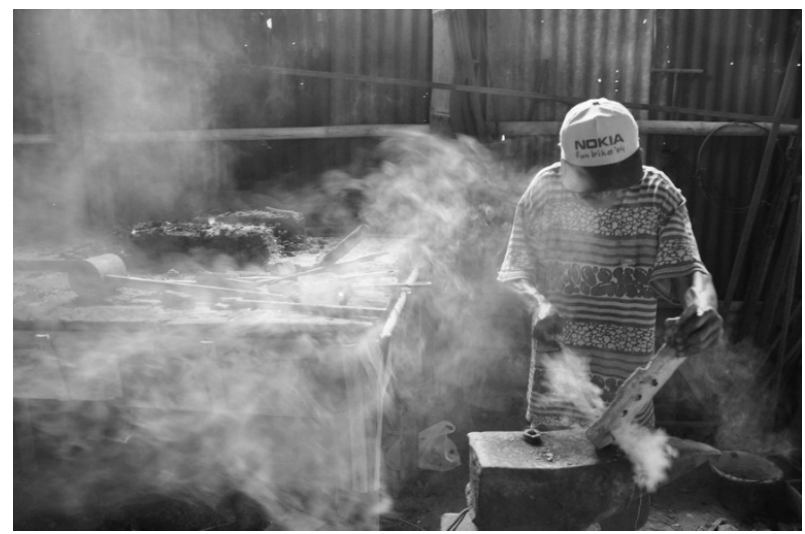

Entire 4. Aktivitas di ruang pengapian.

\section{Detail: Pengambilan gambar yang} terfokus pada bagian kecil dan penting

Detail-detail peralatan dan aktivitas bengkel dijadikan fokus pemotretan.

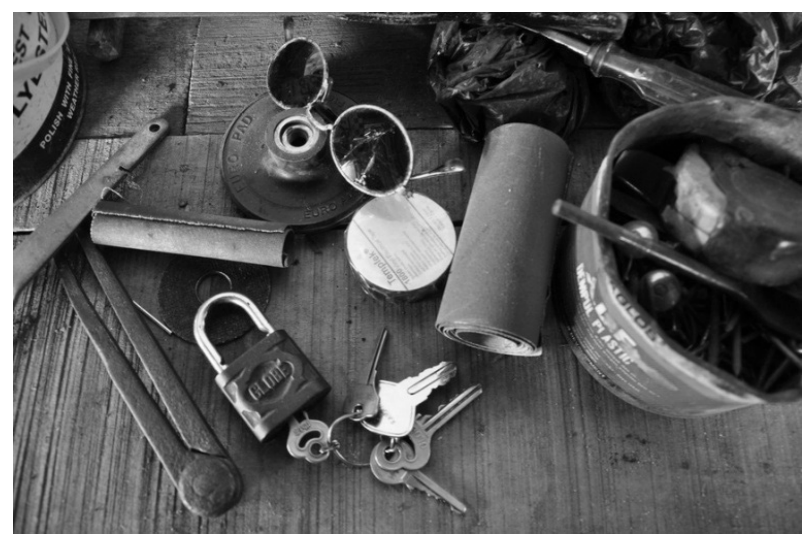

Detail 1. Peralatan-peralatan yang digunakan.

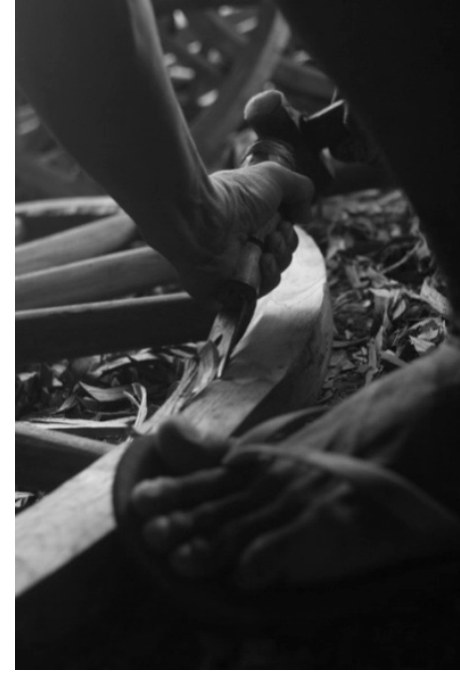

Detail 2. Proses pembentukan velg ban andong.

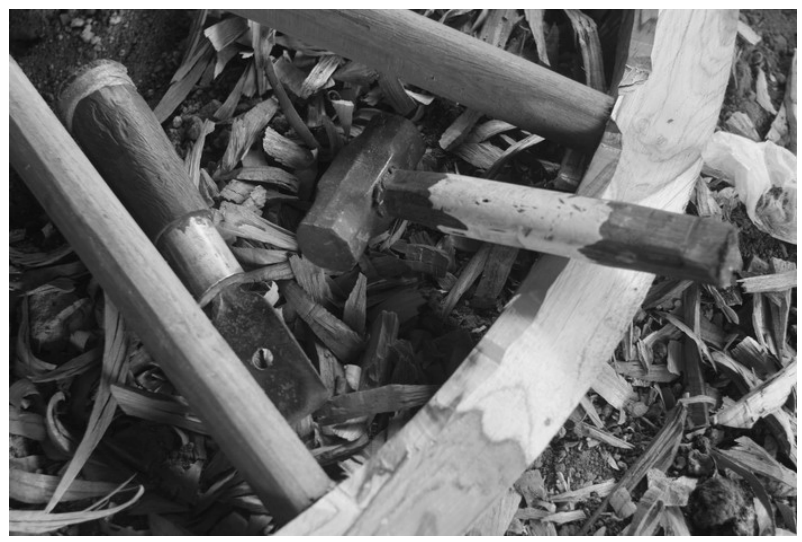

Detail 3. Velg, palu, dan pahat.



Detail 4. Proses pembuatan ulir pada as roda yang rusak. 




Detail 5. Pemasangan lacquer.

\section{Frame: Pembingkaian photo shot} sebagai aspek estetis.

Pembingkaian dijadikan elemen penguat suasana dan pesan dalam gambar.

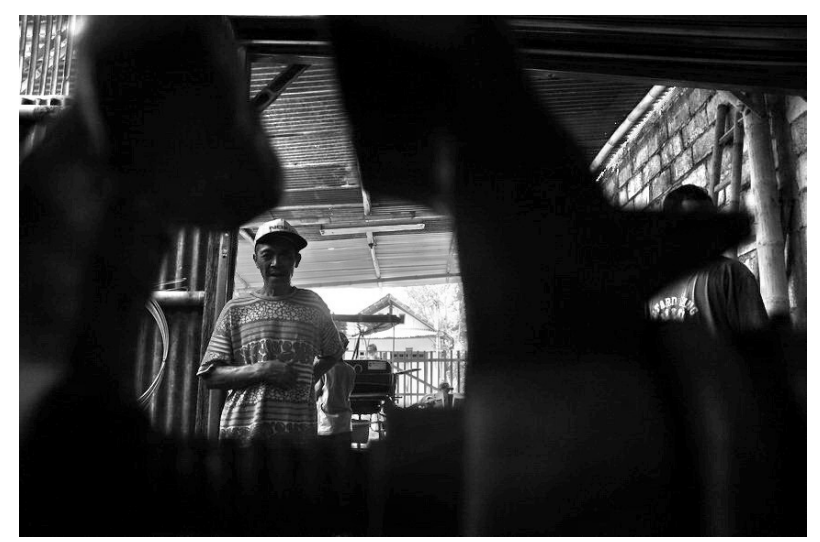

Frame 1. Pekerja di dalam bengkel.

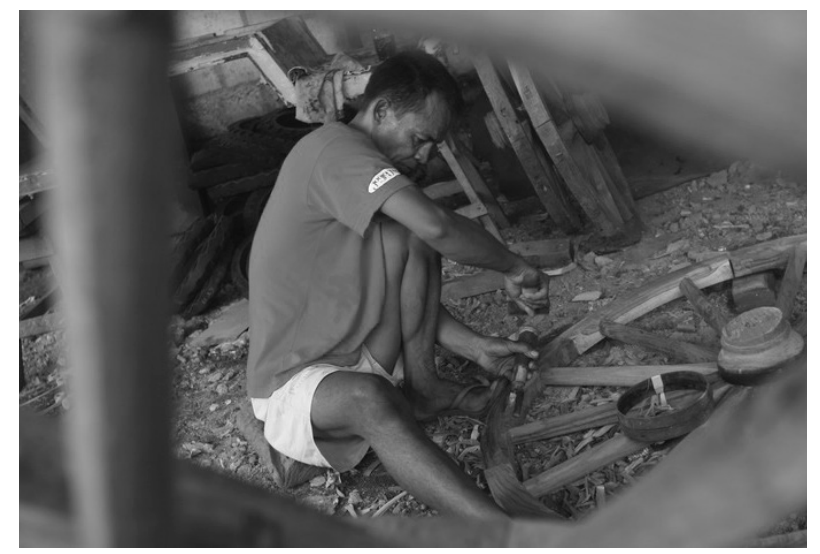

Frame 2. Pembentukan velg kayu.

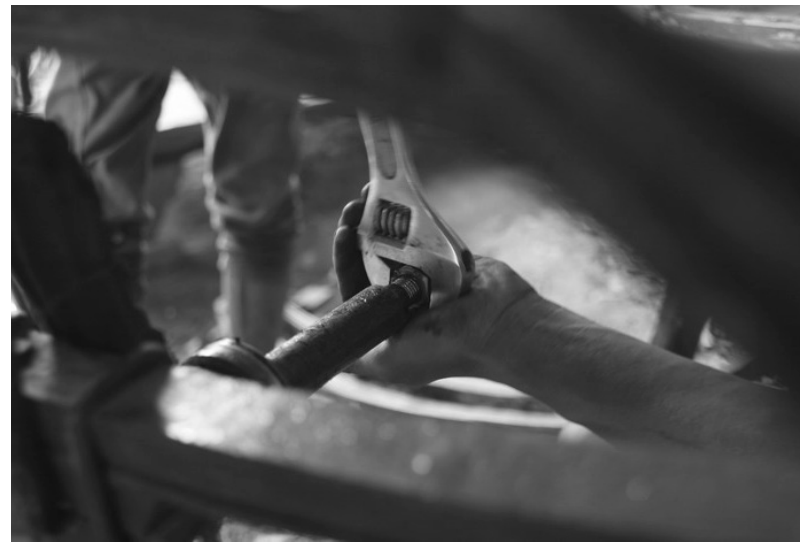

Frame 3. Pemasangan baut.

\section{Angle: Sudut pengambilan pemotretan/} sisi pandang

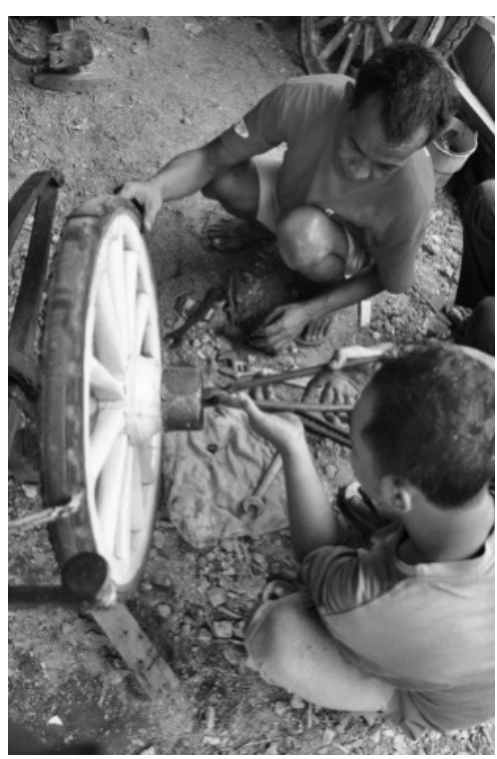

Angle 1. Penyetelan roda.



Angle 2. Pembuatan ulir. 


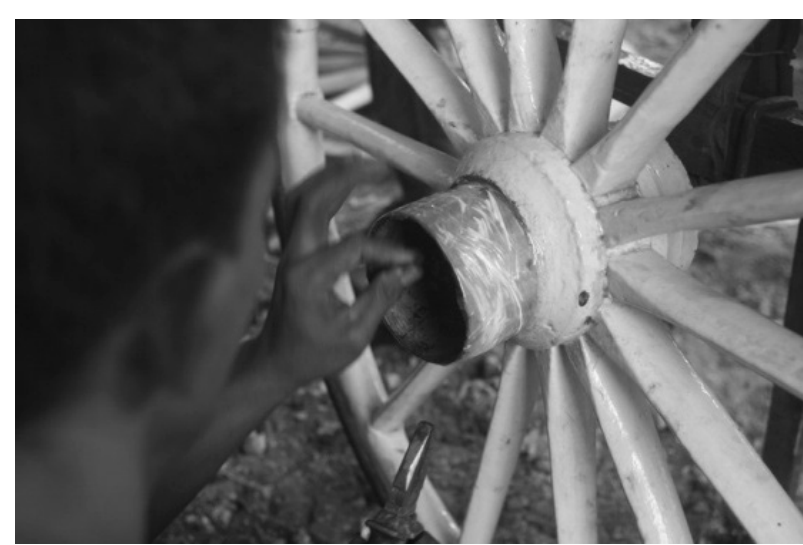

Angle 3. Pemasangan roda.

\section{Time: Waktu kecepatan rana}



Time 1. Proses pemanasan besi.

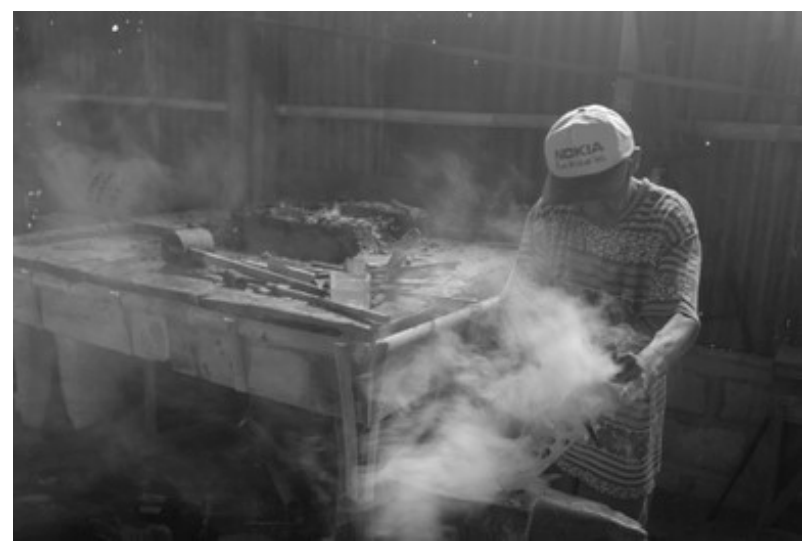

Time 2. Proses pelubangan kayu.

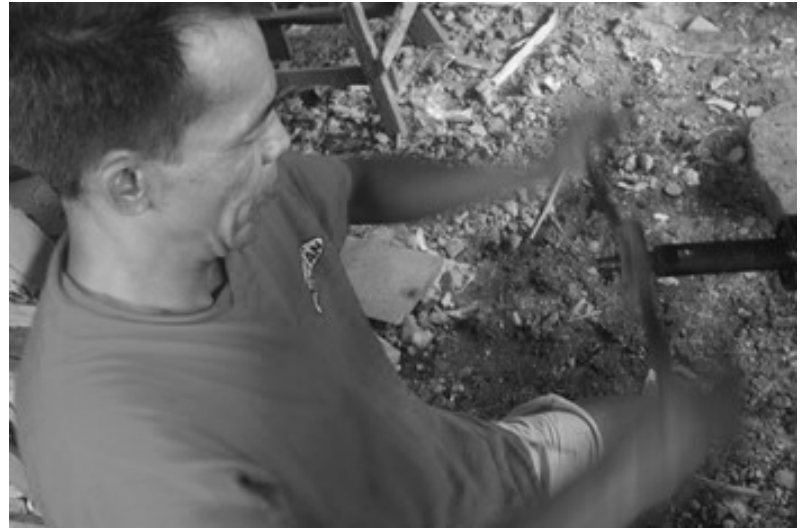

Time 3. Pembuatan ulir di as roda.

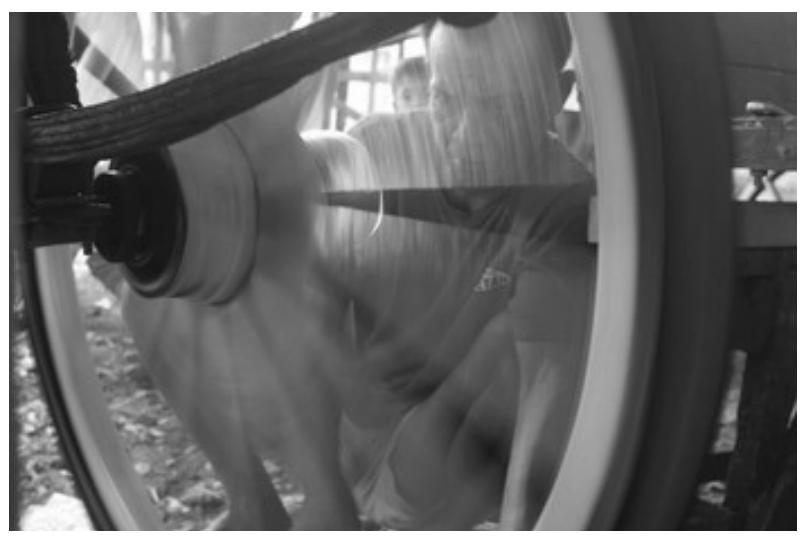

Time 4. Pemeriksaan putaran roda. setelah diperbaiki. Pemotretan dilakukan dengan slow speed.

Foto-foto tersebut terbagi menjadi lima kelompok berdasarkan prioritas pemotretan. Sebagaimana telah diulas pada bagian terdahulu, prioritas tersebut meliputi entire, detil, frame, angle, dan time. Penerapan entire pada bengkel andong menghasilkan foto-foto yang menggambarkan lokasi, aktivitas, dan benda-benda secara utuh atau umum. Maksud utuh di sini bukan dalam arti seluruh objek terlihat dalam bingkai foto, melainkan dapat memberikan keterangan visual secara umum. Dalam konteks ini, entire pada bengkel andong adalah ruang depan, ruang pengapian, aktivitas perbaikan andong, pelanggan, dan bengkel andong secara keseluruhan. Selanjutnya ialah prioritas detail. Dalam bagian ini, bagian- 
bagian yang merupakan unsur penting dalam bengkel andong ditampilkan secara closeup hingga extreme close-up. Detail peralatan bengkel; tangan yang sedang memahat berikut kayu pahatan yang hampir terlepas dari kayu induknya; dan detail tangan pekerja yang sedang memperbaiki as roda merupakan contoh objek-objek pemotretan yang dapat diwujudkan sisi detailnya. Prioritas berikutnya ialah frame. Dalam pemotretan yang memprioritaskan frame, objek terlihat lebih fokus dan mengundang perhatian mata. Pemotretan semacam ini selain menambah nilai artistik foto, juga dapat memberikan informasi tambahan, yaitu suasana dan kondisi di sekitar objek pemotretan. Kesan dramatis sering kali dihasilkan dengan pemotretan yang menitikberatkan pada angle atau sudut pandang pemotretan. Selain informatif, foto dengan prioritas angle juga memberikan kesan keluasan kepada pemirsa foto. Terakhir, pemotretan dengan prioritas time menitikberatkan pada momen-momen penting dalam sebuah rangkaian kejadian. Terdapat dua kemungkinan dalam pemotretan tersebut, yaitu penggunaan kecepatan rana tinggi dan rendah. Kecepatan rana tinggi akan menghasilkan gambar yang "beku" sehingga dapat merekam kejadian yang hanya terjadi dalam waktu yang singkat., sedangkan kecepatan rana rendah akan menunjukkan kesan gerak pada objek yang dipotret.

Penyajian foto-foto bengkel andong yang telah diseleksi berdasarkan teori EDFAT akan dilakukan dengan cara aransemen ulang, penambahan narasi, dan penambahan caption. Artinya foto-foto tadi dikemas dalam format foto esai. Mengingat foto-foto ini bertujuan untuk memberikan gambaran umum tentang Bengkel Andong Mbah Musiran, narasi yang dibangun lebih bersifat informatif. Dalam konteks ini, diceritakan sejarah singkat bengkel andong dan kondisinya saat ini. Untuk melengkapi narasi, caption dicantumkan di semua foto yang terbagi dalam beberapa kelompok. Untuk menambah kesan dramatis dan karakter foto, foto esai ini disajikan dalam format hitam putih. Hasil dari aransemen dan penambahan narasi dapat dilihat berikut ini.

\section{Foto Esai Bengkel Andong Mbah Musiran}

\section{Bengkel Andong Mbah Musiran}

Tak tok tak tok tak tok.... selalu terdengar di Bengkel Andong Mbah Musiran yang terletak di Desa Salakan, Jotawang, Yogyakarta.

Suara benturan gagang tatah dan palu diselingi bunyi desingan mesin bubut ini menjadi musik ritmis mengiringi para pekerja yang mereparasi atau memproduksi andong. Sesekali tercium bau kayu terbakar ketika para pekerja sedang melubangi spare part kayu andong dengan besi yang sudah dipanasi.

Sudah belasan tahun Bengkel Andong Mbah Musiran ini melakukan aktivitasnya. Sekarang bengkel tersebut sudah sedikit demi sedikit dipindahkan pengelolaannya kepada anaknya. Selain mereparasi hampir semua andong yang beroperasi di wilayah Jogjakarta, bengkel ini juga melayani pesanan untuk membuat andong baru. Pesanan andong menurut tuturan Mbah Musiran (70) tidak hanya datang dari para kusir andong, tetapi juga datang dari manca negara yang digunakan untuk kereta kerajaan atau kereta wisata. "Biasanya yang memesan dari luar negeri itu dari Eropa Mas", tuturnya. "Untuk memproduksi satu andong lokal butuh waktu 3-5 bulan, tapi kalau pesenan dari luar negeri bisa setahunan Mas," tambahnya. 
Bengkel Andong Mbah Musiran ini merupakan salah satu pekerjaan langka untuk zaman sekarang karena alat transportasi sudah digantikan oleh mesin. Semoga bengkel ini tidak tergilas oleh roda teknologi karena apa pun yang dikerjakan bengkel ini sudah turut melestarikan budaya transportasi tradisional.....
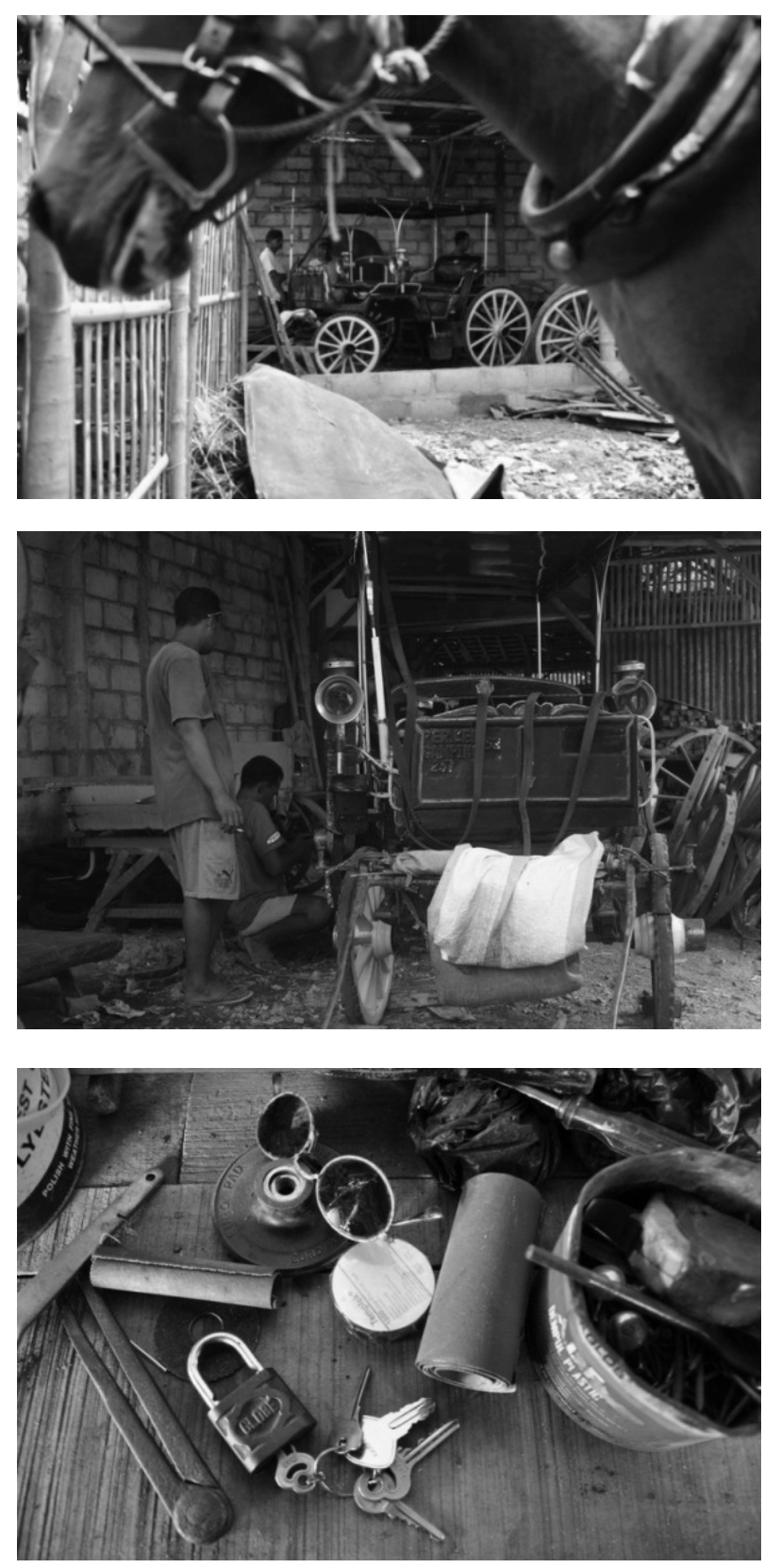

Khusus. Suasana Bengkel Andong Mbah Musiran di Desa Salakan, Jotawang, Yogyakarta
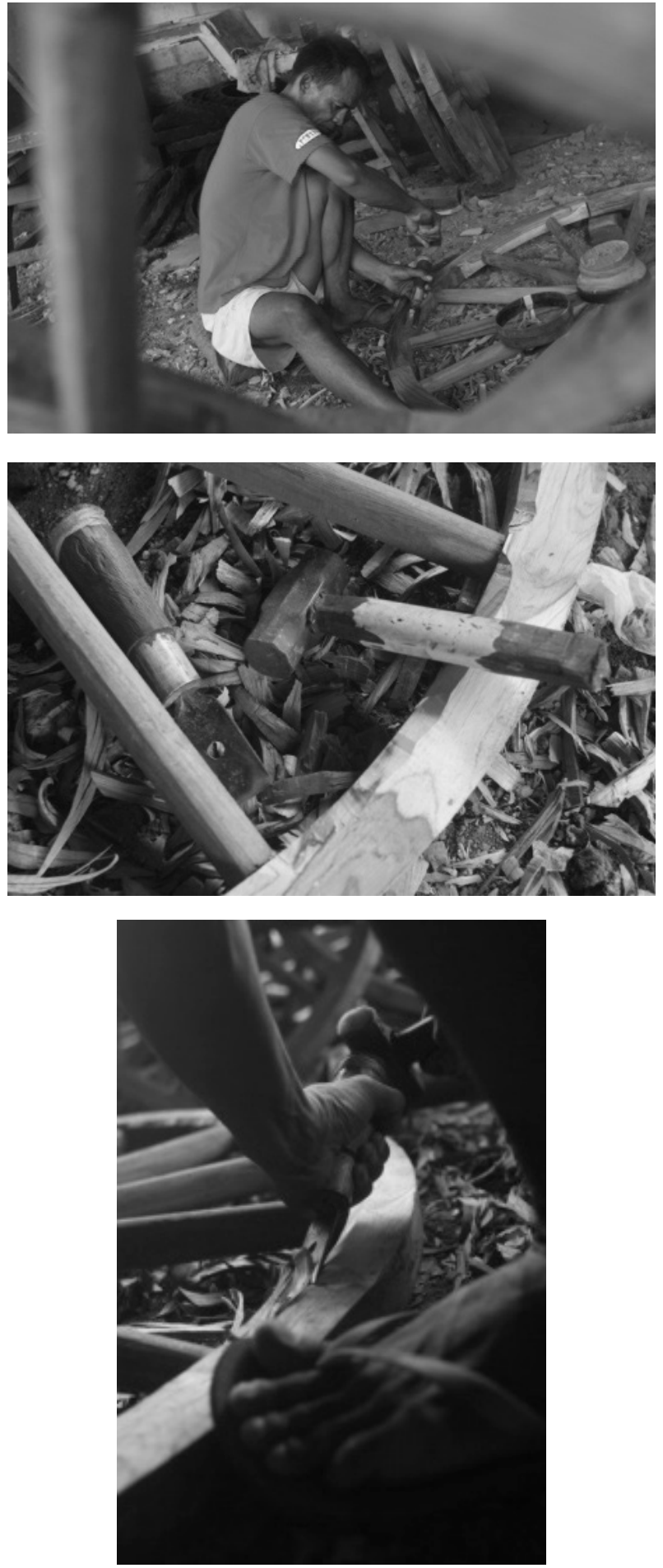

Membuat Velg. Velg dari kayu dibentuk dengan menggunakan tatah dan palu. 

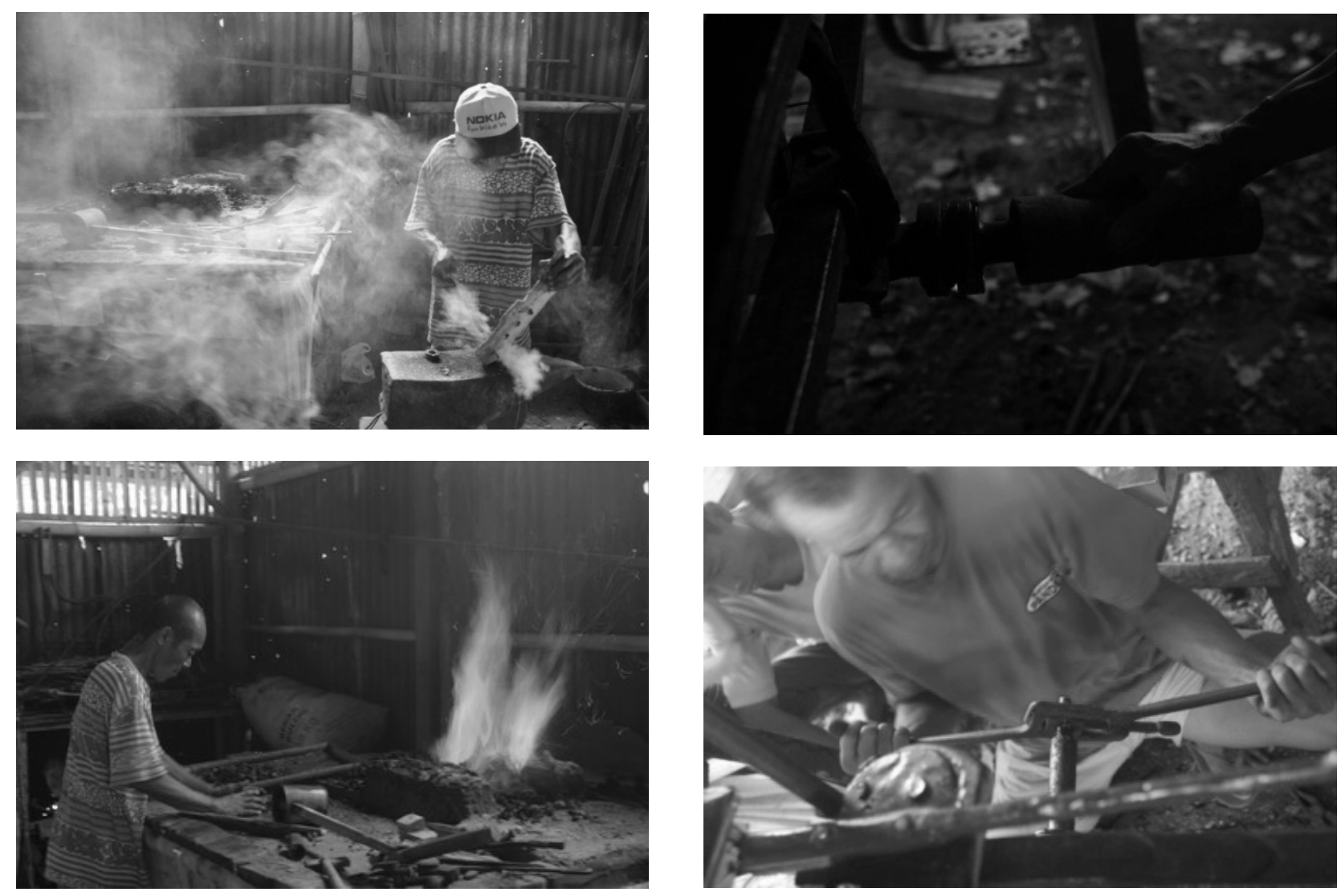

Melubangi. Spare part kayu andong dengan besi yang sudah dipanasi.
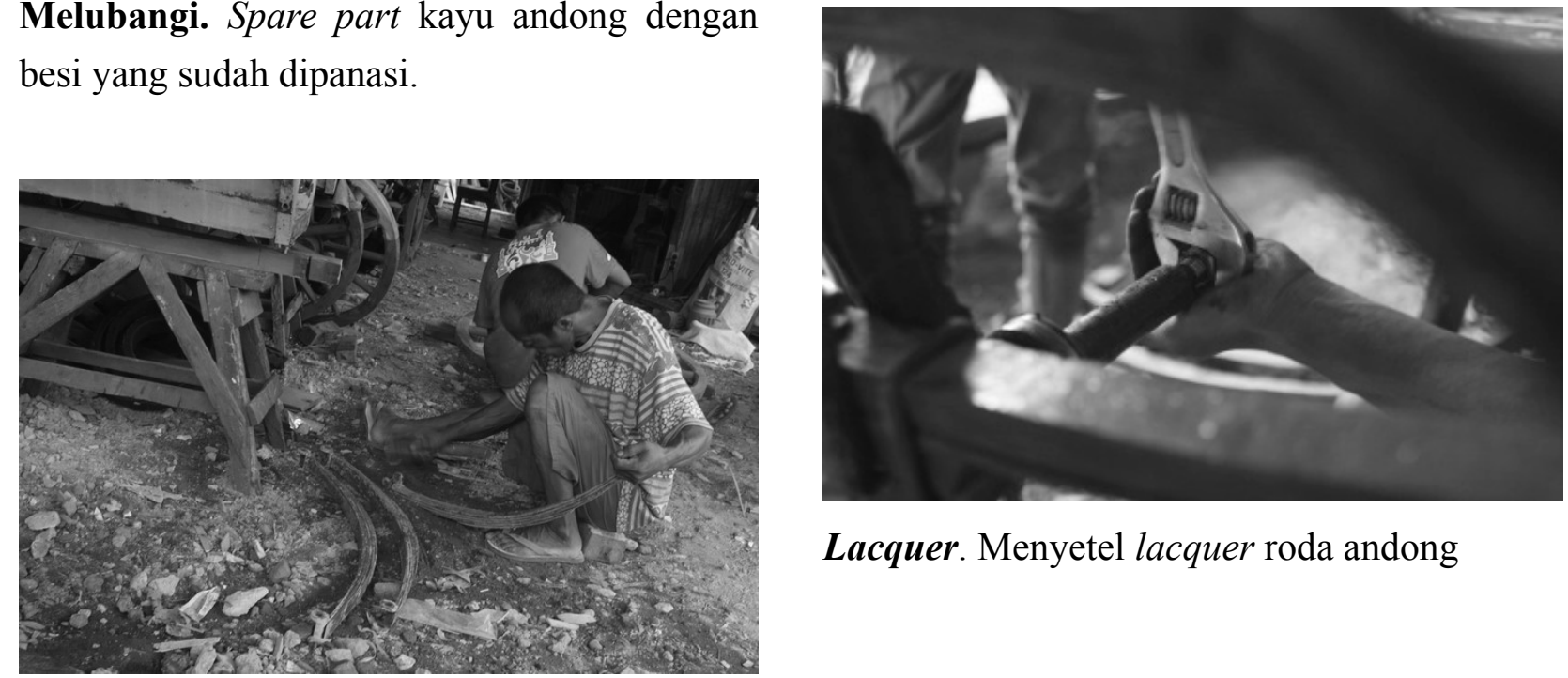

Lacquer. Menyetel lacquer roda andong

Suspensi. Mereparasi besi suspensi andong. 

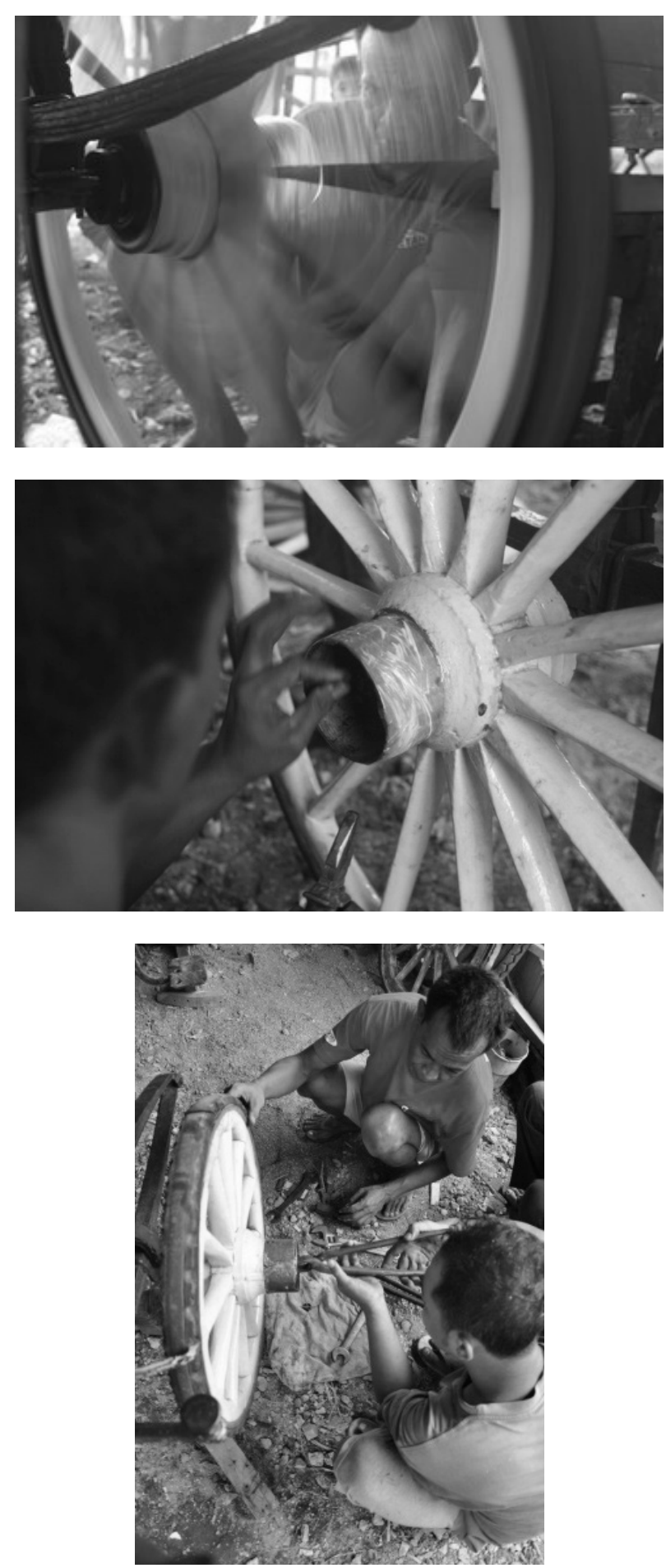

Stel Roda

\section{SIMPULAN}

Penerapan EDFAT pada kenyataannya memang cukup efektif bila digunakan sebagai pemandu dalam pemotretan dokumenter. Buktinya, dengan melakukan tahapan-tahapan pada EDFAT banyak informasi yang dapat disampaikan melalui foto-foto yang dihasilkan.
Akan tetapi, dari sisi lain akan lebih baik jika penerapan EDFAT didahului dengan pembangunan alur cerita atau fokus tema yang akan diangkat dalam bentuk karya fotografi. Dalam kasus pemotretan di Bengkel Andong Mbah Musiran, pemotretan tidak didasari oleh alur cerita ataupun tema tertentu, namun hanya dilakukan dengan tujuan memberikan gambaran umum tentang sebuah lokasi pemotretan. Hal itu akan mengakibatkan terlalu banyaknya pilihan objek pemotretan. Penghimpunan informasi awal tentang objek pemotretan mutlak diperlukan agar fotografer dapat menentukan alur cerita yang ingin dibangun.

\section{KEPUSTAKAAN}

Nugroho, W. W. (2006). Kehidupan Andong di Yogyakarta dalam Fotografi Dokumentasi. ISI Yogyakarta.

Peres, M. R. (2007). Focal Encyclopedia of Photography: Digital Imaging, Theory and Applications, History, and Science. Amsterdam: Focal Press.

Shobri, F. (2010). Fotografi Pementasan Teater Dengan Teknik Freeze Motion Di Dalam Gedung Pertunjukan (Analisis visual foto pementasan Maaf-Maaf-Maaf dan Sayang Ada Orang Lain produksi Teater Lakon UPI Bandung ). Universitas Komputer Indonesia.

Streisel, J. (2007). High School Journalism: A Practical Guide. North Carolina: McFarland \& Company Inc. 